\title{
Work and Life. Balance or Conflict? Theoretical Context vs. Research Results
}

\author{
Renata Tomaszewska \\ Aleksandra Pawlicka \\ Kazimierz Wielki University in Bydgoszcz \\ Poland
}

\begin{abstract}
Summary:
The subject literature analyses as well as the social life practice show that there has been a progressive lack in the work-life balance of individuals nowadays. As a result, people suffer from disturbances in their physical, mental and social development, and the organisations that employ them suffer from their poorer performance, too. Popularising the knowledge and developing the ability to combine work and the life outside it are one of the major challenges for contemporary societies, all the more since healthy and sustainable lifestyles of the employed individuals foster both their personal development and the development of organisations. The aim of the article is to present the selected results of the Professional work - personal life. Balance or conflict? study. According to the applied methodology, after the aim and the subject of the study were determined, the diagnostic poll method was employed. Based on the theoretical scientific analyses present in the subject literature an original questionnaire was designed, which then was responded to by 800 employers working for 80 Polish companies. The main conclusion drawn from the empirical research results pointed out strong work ethos and progressive imbalance in the professional work - personal life relations that the people in the studied group were not aware of.
\end{abstract}

Keywords: work, personal life, balance, conflict, the individual, organisation, civilisation, scientific research, social policies

\section{Introduction}

Human's life is being seen as the symbiosis of the various spheres of their activity. Amongst them, the spheres of professional work and the broadly understood personal life are of special, profound significance. Both the spheres are mutually dependent and closely related. Professional work satisfies numerous needs that personal life creates, and personal life, in turn, may enrich and supplement the sphere of work. The dynamics and vicissitude of the world around us, concerning all the aspects of life, may be perceived as the most general factor that does not foster balancebetween the aforementioned spheres, which manifests itself in the fact, that they are perceived as mutually contradicting. The ongoing civilizational changes may be considered in many perspectives and many contexts. The perspectives may comprise:

1. The change in the way economic life is organised, which takes place and verifies the previous experiences, at the same time at the micro-, mezzo- and macrostructures of the economy;

2. The change in the way social life is organised, during which there happens the reorganising of the basic social structures, individual and collective spaces, the rebuilding of the existing social world;

3. The change in the living conditions of the individuals, in which the questions of keeping the subjective character of individuals' participation in the process of the change itself are of utmost importance ${ }^{1}$.

From the perspective of this paper's topic, the changes in human work are particularly significant. One may point out a number of the particular phenomena that hinder keeping one's balance between professional work and personal life, but despite the subject literature being voluminous, they are not going to be analysed in detail here. Some examples that the researchers signalise most frequently are:

- Exceeding the actual work time beyond the regulatory standards, which automatically leads to the shortening of the time outside work and thus disrupting the work - life balance,

- Working at multiple posts at once - usually owing to the financial factor -appropriating the time outside the basic professional work,

- The even more visible tendency of workers to develop professionally, which at the same time is what the employers expect of them, and which requires devoting time outside professional duties to it, thus disturbing the balance between work and personal life,

\footnotetext{
${ }^{1}$ R. Gerlach, Pozaszkolna edukacja zawodowa wobec zmian cywilizacyjnych. Nowe trendy i wyzwania, Wyd. UKW, Bydgoszcz 2012 , p 9. 42
} 
- Growing and constantly changing requirements of the labour market generate the need for lifelong learning, taking place mostly in the time outside work,

- Visible changes in the managements that cause deviating from the meticulous and routinized workers' supervision; one may also notice the tendency to shift the responsibility for workers' educational and professional activity onto them, outside the statutory work time,

- Flexible employment forms, the even more frequent application of which does not always foster personal life by disrupting the balance; shift, night and weekend work are the cause of one's absence, diseases, decrease in motivation,

- Crew deficiencies, which are even more often reported by the employers, may contribute to overburdening the employees with work, imposing more duties on them, prolonging their working time and thus disrupting the balance between professional and non-professional activity ${ }^{2}$.

The demands of professional work more and more often connect and intertwine with the extraprofessional activity, this is why building and maintaining balance between those two spheres of one's biography is an issue that has been repeatedly raised in the recent years. The deliberations presented in this paper concern the selected issues of this research area.

\section{The introduction to the conceptual category of 'Work-Life Balance'}

The subject literature devoted to the relations between professional work and personal life has become more and more comprehensive. It particularly concerns the so-called 'life balance', which comprises the concept of work-life balancedescribed by many authors, who have drawn attention to its various aspects. Such studies encompass both scientific publications, which are the primary sources of knowledge, and the popular science materials that are secondary sources, at the same time playing the didactic and popularising roles.

As regards the deliberations presented in this paper, one may adopt the stance of David Clutterbuck who believes that the essence of the balance between professional work and the extraprofessional sphere is the state in which the individual manages the prospective conflict between numerous demands on their time and energies in such a way, that their need for well-being and fulfilment is being satisfied. In this case, the term 'balance' means stability and common sense as well, in other words some subjective, culturally-determined ideas of what is sensible or what is the personal equilibrium of the particular individual. The occurrence of the conflict between work and one's personal activity does not necessarily mean the lack of balance. In order for it to occur, there must arise some real or subjectively perceived effects of the conflict. Thus, it is also important to be able to adapt to the conflict situation and deal with it. As Clutterbuck points out, achieving balance between professional and private lives comes down to: realising the requirements concerning investing one's time and energies; the ability to make choices related to these investments; selecting the values those choices should base on; as well as making conscious choices ${ }^{3}$.

The scope of 'work-life balance' is undoubtedly vast. The term comprises all the needs of the individual within their professional and extraprofessional spheres. Sue Campbell Clark defines 'work-life balance' as good functioning and satisfaction at home and at work which is achieved by minimising the conflicts existing in both those spheres, and also the ones that result from going beyond the personal and private spheres ${ }^{4}$, which emphasizes the mutual relation of the both spheres and the conflicts that may occur within them ${ }^{5}$.In order to set the borders of work-life balance one may also use the organisational work-life continuum by Nora Spinks, in which, starting from the negative pole and going towards the positive one, there are: the level of conflict, interference, balance, integration and harmony ${ }^{6}$.

When analysing this conceptional category, one must pay attention to the fact, that there have been given new suggestions on how to define the essence of balance. All their components fall into the idea of work-life balance, as they popularise the striving for maintaining harmony based on the values that we find the most important (work-life integrity); taking care of the quality of life (work-life quality); as well as of the rhythm of one's day and managing

\footnotetext{
${ }^{2}$ See. R. Tomaszewska-Lipiec, Work transformations and their consequencesfor the personal life of workers, 'Chinese Business Review', Vol. 15 Issue:Number 5, 2016, pp. 239-248; R. Tomaszewska-Lipiec, Praca zawodowa-życie osobiste. Dysonans czy harmonia?, UKW, Bydgoszcz 2018, p. 384.

${ }^{3}$ D. Clutterbuck, Równowaga między życiem zawodowym a osobistym, Oficyna Ekonomiczna, Kraków 2005, p. $26.26-27$.

${ }^{4}$ S.C. Clark, Work/family border theory: A new theory of work/family balance, „Human Relations”, 2000, Volume 53, Issue 6, pp. 747-770.

${ }^{5}$ See: M. Westman, P. Brough, T. Kalliath, Expert commentary on work-life balanceand crossover of emotions and experiences: Theoretical and practice advancements, 'Journal of Organizational Behavior', 2009, Volume 30, Issue 5, pp. 587-595.

${ }^{6}$ N. Spinks, Work-life balance: Achievable Goal or. Pipe Dream?, „,The Journal for Quality \& Participation, 2004,Volume 27, Number 3, pp. 4-11.
} 
one's productivity (work-life rhythm) ${ }^{7}$.Stew Friedman, instead of the term 'work-life balance' uses the term work-life integration, also called work-life integrity.

This is because, as the author notices, the concept of work-life balance initially suggested a struggle between home and work, but disregarded the very salient fact that 'life' actually comprises of the interactions between four domains: work, home, society and one's own self. ${ }^{8}$ Frederic Laloux claims that the concept of 'work-life balance' emphasizes the separation of work and life, which clearly shows how little of life there remains in work, if we part from what really matters. At present -in the context of the dynamically changing times and the Millenials' and $\mathrm{Z}$ generations - the term work-life blending has been used regularly, as it illustrates the essence of the blending of the professional and private lives ${ }^{9}$.On the other hand Ron Ashkenas ${ }^{10}$ highlights the fact that the boundaries between those two areas are becoming untight and mobile. According to him, we should all accept the fact that the distinct division between one's work and home is a thing of the past. Concentrating on work-life integration instead of work-life balance requires rethinking both the way we organise our work and lives.

The analysis of the scientific literature thus allows one to present several diverse approaches to the idea of the balance between professional work and private life; the idea seems to be of such complex and multi-faceted character that it should become a key area of the contemporary scientific research.

In the 'European Quality of Life Survey' report ${ }^{11}$,comprising 28 member states, there was the diagnosis established of the level of the adjustment of the working hours to one's family and social commitments. As regards the employees (according to the activity status category), the European average for the answer 'Rather well or very well' was $78 \%$. The score for Poland ${ }^{12}$ was higher than the European average $-84 \%$, which has been illustrated in the Chart 1 .

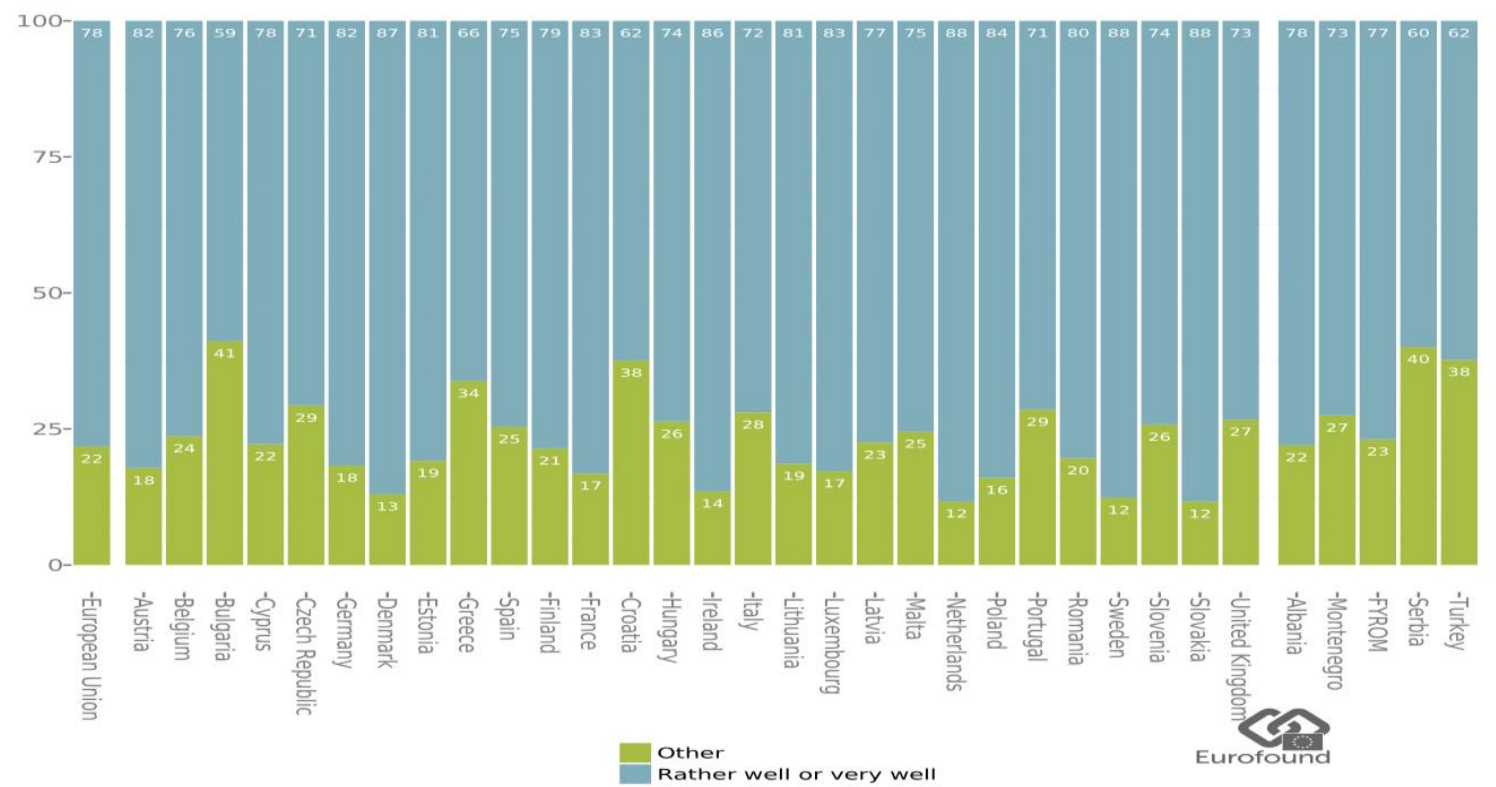

The category 'Other' comprises the sum of the answers in the categories: rather bad, very bad, I don't know and no answer.

Chart 1. 'Rather well' or 'Very well' level of how one's working hours fit in with their family and social commitments in UE-28 (\%).

\footnotetext{
${ }^{7}$ R. Tomaszewska-Lipiec, Praca zawodowa-życie osobiste. Dysonans czy harmonia?”, UKW, Bydgoszcz 2018, p. 66.

${ }^{8}$ S. Friedman, What Successful Work and Life Integration Looks Like, „Harvard Business Review”, October 2014.

${ }^{9}$ F. Laloux, Pracować inaczej, Studio Emka, Warszawa 2016

${ }^{10}$ R. Ashkenas, Forget Work-Life Balance: It's Time for Work-Life Blend, „Forbes”, October 2012.

${ }^{11}$ Eurofound, European Quality of Life Survey 2016, https://www.eurofound.europa.eu/pl/data/european-quality-of-lifesurvey [13.01.2018]. As part of the European Quality of Life Survey, almost 37,000 people in 33 countries - 28 member states and 5 candidate countries (Albania, the former Yugloslav Republic of Macedonia, Montenegro, Serbia and Turkey) were interviewed.

${ }^{12}$ As regards Poland, it is worth underlining that although the Polish people belong to the nations that work the longest hours in the European Union, the productivity of work is almost the lowest in Europe. Long time spent at work does not also equal the affluence of the society, as the shorter working time is characteristic of the countries with the high GDP per capita.
} 
Source: Eurofound, European Quality of Life Survey 2016, https://www.eurofound.europa.eu/pl/data/european-qualityof-life-survey [13.01.2018].

Although the presented data seems to be hopeful, according to the statistical information obtained in the European Quality of Life Survey, 59\% of the studied group employed in the UE-28 declared they come home too tired to be able to carry out their household duties at least a few times a month. The average for Poland was $63 \%$. Moreover, $39 \%$ of the respondents claimed that owing to the time spent at work they found it difficult to fulfill their family commitments at least a few times a month. For Poland, this average was 50\%. It is worth noting that $19 \%$ of the surveyed EU-28 employees declared facing difficulties in concentrating on work because of family commitments. The average for Poland was $28 \%{ }^{13}$.

In turn, the empirical data published as part of the 'Sixth European Working Conditions Survey' indicates - taking into account the answers of the fixed-term contract, permanent employment and self-employed workers -that $54 \%$ of them felt that they combine their work and personal commitments 'well', and $28 \%$ of them - 'very well', which has also been illustrated in the chart.

The in-depth analysis of the empirical data let one find that as regards this question, 58\% of the Polish respondents declared they do it 'well', and $25 \%$ - 'very well'. However, the categories of 'not very well' and 'not at all well'in Poland scored 14 and 3\% respectively. The EU-28 average was 15\% for the former and $4 \%$ for the latter category.

\section{Chart 2. The level of the mutual fit between work and personal commitments, by country (\%)}

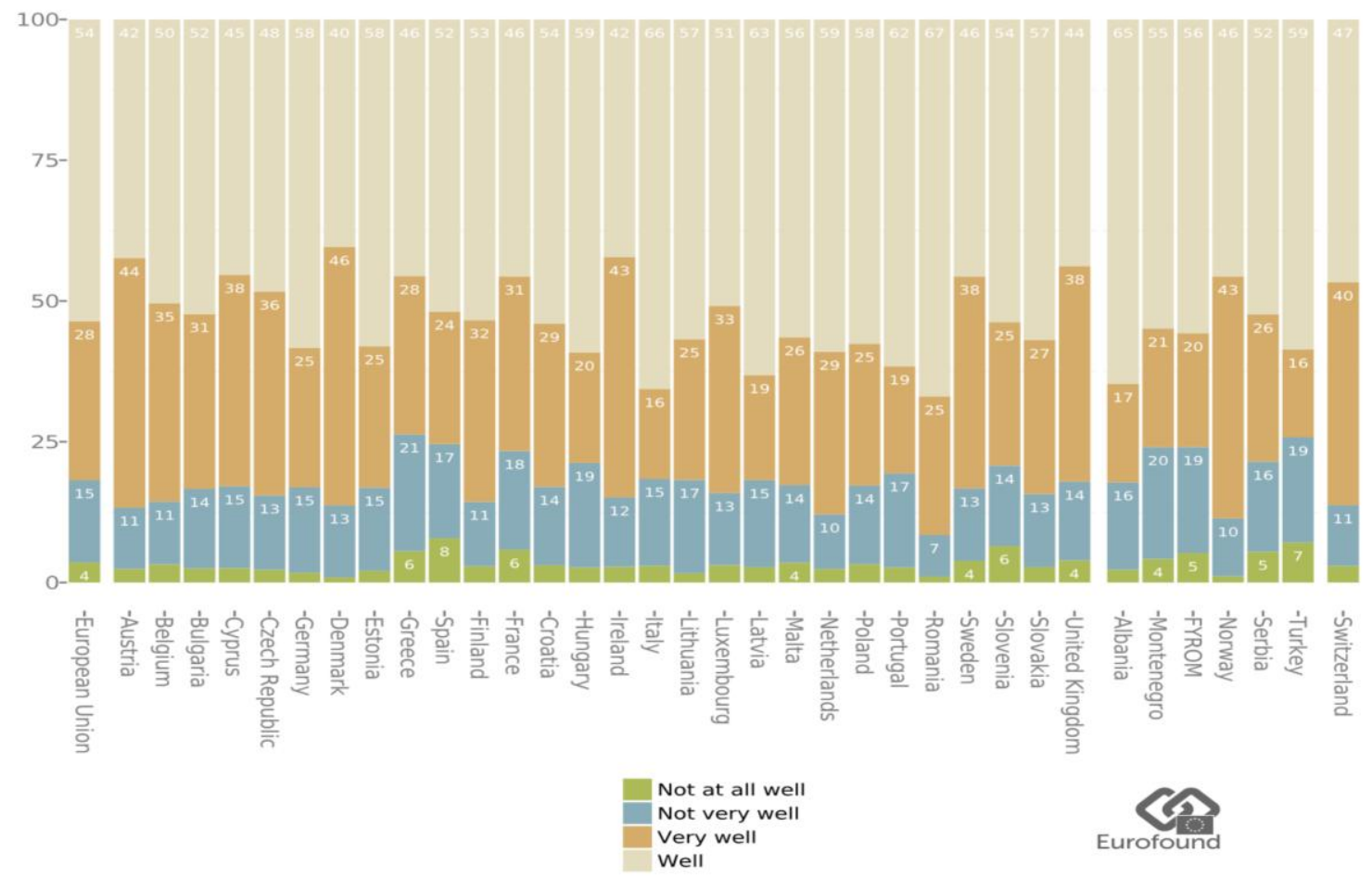

Source: Eurofound, European Working Conditions Surveys (EWCS) 2015, https://www.eurofound.europa.eu/pl/data/european-working-conditions-survey [22.01.2018]

The examples of empirical data quoted above clearly show that the questions of combining professional work and family life, despite being different for every country, are a burning issue of the whole society of the European Union 28.

In the light of the aforementioned, the concept of work-life balance comes out as a potentially vast and inspiring subject of scientific research. The progressing conflict in the mutual relations is a representative example of the increasing irregularity taking place in the world's socio-economic system, both in the developing and developed countries. The conflict is a significant factor that characterises the contemporary work environment, and is related to the safety of

\footnotetext{
${ }^{13}$ Eurofound, European Quality of Life Survey 2016, https://www.eurofound.europa.eu/pl/data/european-quality-of-life-survey [13.01.2018].
} 
workers, their health and the like. Amongst the most serious psychosocial threats resulting from the technical, organisational, socio-economic, demographical and political transformations - including the progressive globalisation that have been identified by the experts of the European Risk Observatory, there are: the new forms of job contracts and the uncertainty of employment, the workforce getting older, the intensification of work, a severe emotional strain at work and the disrupted balance between work and private life ${ }^{14}$.

\section{Work-life balance in the Polish economic practice - selected study results}

The issues indicated in the first part of the paper inspired undertaking original empirical study, of nationwide range. Its main aim was to: identify and explain the character of the relations that result from the influence of professional work over one's personal life, as well as to determine the effects of this influence over the both spheres of employees' functioning. At its first stage, the quantitative analysis was performed using the diagnostic survey method, also called the opinion survey method. The sample was chosen in a purposeful random manner. Amongst the economy sections that constitute the Polish Classification of Business Activities ${ }^{15}, 16$ branches were selected. The study was carried out in 80 organisations chosen at random, which represented each of the branches; 5 organisations for every branch. The database of 80 organisations was created based on the statement delivered by the Statistics Poland. In October 2016 a written request was submitted for drawing 5 business entities which were diversified as far as the employment figure was concerned, in each of the 16 branches of economy. The organisations, after granting consent for being interviewed, were included in the actual sample. In some sections it turned out to be necessary to draw the lots again, even several times, as there were difficulties obtaining consent to conducting the quantitative research in the previously drawn business entities. In each of the studied organisations, 10 workers were selected at random, who then were requested to fill in the questionnaires. Thus, in the end, there were 800 completed questionnaires. The actual survey was preceded by a pilot study.

As far as the studied people are concerned, it is worth mentioning how diverse they were in relation to their sociodemographic characteristics. In this particular sample, there were slightly more women $(51.4 \%)$ than men $(48.6 \%)$. The respondents fell into the following age groups: 18-29 (12.6\%), 30-39 (35.8\%), 40-49 (30.6\%), 50-59 (18.1\%) and 60 years old and more (2.9\%). According to the groups distinguished in the Polish structure of occupations and specialisations, the researched groups comprised of: specialists (30.8\%); office workers (22.8\%); technicians $(10.8 \%)$; service workers/ sales workers (7.6\%); plant and machine operators and assemblers (6.6\%); craft and related trades workers $(4.9 \%)$; legislators, senior officials, chief executives $(4.0 \%)$; farmers, gardeners, foresters and fishermen (1.8\%). Amongst the researched group, the most popular employment form was the permanent employment $(57.6 \%)$ and the fixed term employment $(28 \%)$. It is worth noting that $4.6 \%$ of the respondents ran their own, one-person enterprises; $5.5 \%$ had mandatory contracts; $1.9 \%$ had contracts of specific work, and $1.4 \%$ worked without any contracts. Considering the aforementioned characteristics, one may find that the studied group was representative enough in order for the study findings to allow drawing conclusions and generalities. The selected results of the study have been presented in the following part of this paper.

One of the research problems the Author wished to find the answer to was the question: If, and if yes, in which branches of the Polish economy, the workers think they maintain the balance between their professional work and private lives. In the Table 1, the answers given by the studied group have been compared with two indicative statements, according to the 16 sections of the Polish Classification of Business Activities, which made it possible to provide answers.

\footnotetext{
${ }^{14}$ European Agency for Safety and Health at Work, Expert forecast on emerging psychosocial risks related to occupational safety and health, Luxemburg 2007.

${ }^{15}$ The Polish Classification of Business Activities is a conventional, hierarchically systematised division of the kinds of the socio-economic activities undertaken by individuals (business entities). 
Table 1. The comparison of the answers offered by the respondents with two indicative statements, according to the 16 sections of the Polish Classification of Business Activities (in numbers).

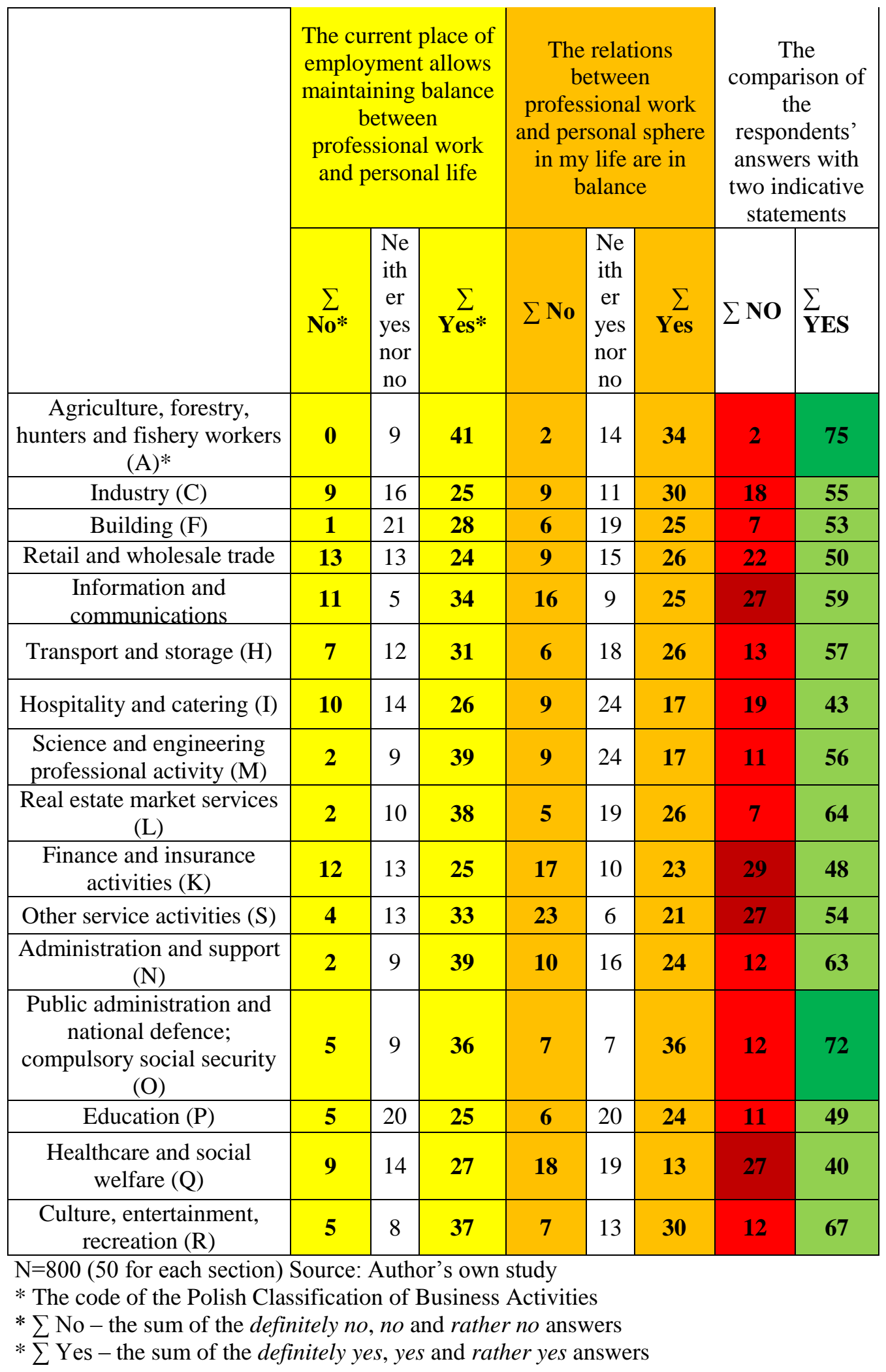

The collected statistical data shows that the most summed up definitely yes, yes and rather yes answers pointing out the 'current place of employment allowing balance between professional work and private life' declared by the employees, as well as their opinion, that their 'relations between professional work and personal sphere are in balance' were given by the representatives for the sections: 
1. A, that is Agriculture, forestry, hunting and fishery, comprising the activities related to: exploitation of natural plant and animal resources, growing grains and other crops, livestock farming, obtaining wood and forest resources, obtaining animals and animal products from farms or their natural environment

2. $\mathrm{O}$ - public administration and national defence; compulsory social security, comprising:

- Legislative and executive activities by central and chief state administration organs, local government administration organs and the self-government organs related to the state functioning as far as the financial, tax, economy, cultural, healthcare and social welfare spheres are concerned,

- Executive activities, related to performing national functions in the spheres of foreign affairs and defence,

- National security, order and public safety activities,

- Administration of the law, including executing judicial sentences, excluding enforcement activities,

- The activity of the publicly funded fire brigades,

- The activity related to the compulsory social security.

In addition to that, the data allowed specifying the four sections of the Classification of Business Activities dominating in Poland, that scored the highest number of summed up definitely no, no and rather no answers. As the table shows, they were the following economy branches of the studied 16 :

1. J - information and communication, comprising: producing and broadcasting information and cultural assets, sharing and publishing those goods, information technology service activities, data processing and other information-related service activities;

2. $\mathrm{K}$ - financial and insurance activities, comprising the activities related to the financial services, including insurance, reassurance, pension fund-related activities and the activities supporting financial services and the activities of holding companies, corporate trusts, funds and other similar financial institutions;

3. Q - healthcare and social welfare, comprising: the healthcare provided by doctors in hospitals or other institutions, physiotherapy, paramedics and emergency healthcare, the social welfare services providing lodgings that require some healthcare services, the social welfare services that do not need engaging medical professionals in any form of support;

4. $\mathrm{S}$ - other service activities, comprising the activity of member organisations, repairing computers and personal and household items, as well as other service activities that have not been classified anywhere else.

In this original study it was also crucial to determine, what significance the respondents attach to work-life balance. The majority of surveyed workers $-82.8 \%$ in total (including the answers: definitely yes, given by $23.9 \%$ of the respondents, yes - by $29.1 \%$ and rather yes by $29.8 \%$ of them) - agreed with the following statement: 'The balance between work and personal life is important to me'. The balance was not important for merely $3.9 \%$ of employees; $13.3 \%$ of them chose the answer neither yes nor no. If one refers here to the 16 selected sections of the Polish Classification of Business Activities, one may notice that among the workers who declared that 'The balance between work and personal life is important to me' and chose the definitely yes answer, there prevailed the representatives for the section $\mathrm{K}$ - financial and insurance services (58\%) and $\mathrm{J}$ - information and communication services (42\% of the answers). It also seems thought-provoking that the definitely no category was indicated exclusively by the representatives of the section $\mathrm{S}$, that is other service activities (2\% of the respondents).

The empirical data showing the distribution of answers concerning the significance of the balance between professional work and personal life in employees' opinion, according to the section of the Polish Classification of Business Activities has been presented in Table 2 . 
Table 2. The significance of the balance between professional work and personal life in employees' opinion, according to the section of the Polish Classification of Business Activities.

\begin{tabular}{|c|c|c|c|c|c|c|c|c|c|c|c|c|c|c|c|c|c|}
\hline \multirow{3}{*}{ No. } & \multirow{3}{*}{ Specific answer } & \multicolumn{16}{|c|}{$\%$ of the answers } \\
\hline & & \multicolumn{16}{|c|}{ The section of the Polish Classification of Business Activities } \\
\hline & & A & $\mathbf{C}$ & $\mathbf{F}$ & $\mathbf{G}$ & $\mathbf{H}$ & $\mathbf{I}$ & $\mathbf{J}$ & $\mathbf{K}$ & $\mathbf{L}$ & M & $\mathbf{N}$ & $\mathbf{O}$ & $\mathbf{P}$ & $\mathbf{Q}$ & $\mathbf{R}$ & $\mathbf{S}$ \\
\hline 1. & Definitely no & - & - & - & - & - & - & - & - & - & - & - & - & - & - & - & 2,0 \\
\hline 2. & No & - & - & - & - & - & 4,0 & 2,0 & - & - & 2,0 & - & - & - & 4,0 & - & 2,0 \\
\hline 3. & Rather no & 6,0 & 2,0 & 2,0 & - & - & 8,0 & - & - & - & 4,0 & - & - & - & 4,0 & 2,0 & 18,0 \\
\hline 4. & $\begin{array}{c}\text { Neither yes nor } \\
\text { no }\end{array}$ & 14,0 & 16,0 & 16,0 & 10,0 & 14,0 & 20,0 & 10,0 & 2,0 & 14,0 & 22,0 & - & 8,0 & 14,0 & 20,0 & 8,0 & 24,0 \\
\hline 5. & Rather yes & 36,0 & 28,0 & 20,0 & 38,0 & 30,0 & 32,0 & 28,0 & 12,0 & 42,0 & 34,0 & 60,0 & 28,0 & 22,0 & 20,0 & 24,0 & 24,0 \\
\hline 6. & Yes & 36,0 & 44,0 & 33,0 & 30,0 & 28.0 & 24,0 & 18,0 & 28,0 & 34,0 & 22,0 & 36,0 & 30,0 & 30,0 & 16,0 & 32,0 & 26,0 \\
\hline 7. & Definitely yes & 8,0 & 10,0 & 30,0 & 22,0 & 28,0 & 12,0 & 42,0 & 58,0 & 10,0 & 16,0 & 4,0 & 34,0 & 34,0 & 36,0 & 34,0 & 4,0 \\
\hline
\end{tabular}

$\mathrm{N}=800$

The respondents replied to the aforementioned statements according to the seven-stage answer scale, in which: 1 - meant definitely yes, 2 -no, 3 -rather no, 4-neither yes nor no, 5 -rather yes, 6 -yes, 7 -definitely yes.

When presenting the selected results of the study in this paper, it ought to be strongly emphasizedthat in the group of 800 Polish workers:

- In case of the $43.4 \%$ of respondents the actual number of work hours was greater that the statutory one (40 hours), predominately owing to the requirements of the workplace or the function performed in it;

- $52.5 \%$ of workers did not mind fulfilling their work duties after their regular business hours, of different intensity, and $56.1 \%$ claimed they take some specific workplace duties home, also with various intensity,

- $\quad 45.4 \%$ of the respondents worked overtime and $26.9 \%$ took up additional employment,

- only $38.6 \%$ of the employees did not experience any negative influence of work over their personal lives, which may be the evidence of the existence of disharmony in the mutual relations between professional activity and private lives,

- the respondents declared that due to work they do not have time for: pursuing their interests, travelling and personal development $-26.4 \%$ of the answers; going to the cinema, theatre, exhibitions, sporting events, etc. $-23.3 \%$; leisure time devoted to sleeping; entertainment, relaxation $-17.5 \%$; meeting friends and acquaintances $-16.4 \%$; performing the roles of a: son/daughter, husband/wife, father/mother - 13.9\%; education - 13.3\%, as well as social work, belonging to the non-governmental/civic organisations and to the Church $-8.9 \%$,

- part of the respondents believed that the lack of 'balance' between professional work and personal life adversely influences the speed and quality of their performing their professional duties $-38 \%$ and the atmosphere and relations at the workplace $-48.1 \%$

- the conflict between professional work and personal life was considered to be a natural state by part of the respondents; looked upon as an element of reality, in which the individual is forced to work and the time and energy resources that could be invested in other spheres of life are, in fact, scarce. Only $23.5 \%$ of the respondents declared having recognised the demands resulting from fulfilling professional duties and personal life commitments, as well as having sought the ways of resolving the conflict between the roles they play.

Wrapping up the presented reflections, one may reach the conclusion that professional work is an invaluable and desired asset. However, the sphere of one's professional activity inspires the blurring of the boundaries between professional work and personal life. There is the increasing pressure to be available to work, ready for challenges and to win employer's regard. The main conclusion drawn from the empirical analyses is as follows: the conflict in the professional work - personal life relations is plainly visible. The conflict - as it has already been indicated - may be considered to be one of the psychosocial threats. Counteracting this threat requires increased awareness, among both individuals and organisations. It seems that the most effective way would be to provide efficient preventive mechanisms and to develop remedial competences, of both employers and employees. In this respect, the following actions deserve being given rapt attention:

1. The preventive ones, that is the developing of communication skills of workers and the ability to determine priorities and manage one's time; fostering social contacts; education about work pathologies; reaching sociological diagnoses, 
2. The organisational ones, that is flattening organisational structures; the effective way of disseminating information; determining worker's duties, competences and responsibilities in a precise, unambiguous manner; a clear system of employees' evaluation and remuneration adequate to the devoted effort; diminishing or ridding the workplace of stressors, adjusting the workplace and tasks to the employer; changing some particular aspects of work; identifying the 'time thieves'; applying flexible employment forms; organising various forms of leisure and psychophysical regeneration;

3. The mediatory ones, that is taking care of the proper preparation of social competences of the specialists that manage human resources and managers; the readiness for negotiating; protecting one's privacy; the openness of the organisation to cooperate with external specialist companies and ensuring cooperation within this area with trusted specialists,

4. The disciplinary ones, that is firm and consistent leadership; the lists of behaviours that are unacceptable in the company; opposing extreme overworking; temporarily relieving workers of their regular duties owing to their health state, supplementary education, training and improvement, or their family situation ${ }^{16}$.

The results of the original study also imply a crucial postulate - the need of education concerning the dilemma of workers' and family roles; or else: the need of learning how to take care of one's quality of life in its various aspects (physical, mental, emotional ones). When educating professionals job-wise, we must not at the same time create people who develop no sensitivity to non-professional matters, that is people who are "profit-crazy, narrow-minded, individuals with icy hearts and shrunken souls, ${ }^{17}$.

Taking into consideration the volatility of the today's world and preparing future generations for succeeding at work and in life in the $21^{\text {st }}$ century, it is fundamental to equip the individuals with the proper abilities to create one's own paths of life and career. It seems that the abilities to combine professional work and personal sphere, cope with stress and recognise the symptoms of professional burnout should absolutely be amongst them. Thus, they generate the present implications for education. One should make real efforts to develop and promote the idea of balance between work and personal life, as the lack thereof will probably become even more severe.

\section{Conclusions}

The analysis of the issue, both based on theoretical and empirical studies, is really complex and thus it is still insufficient, requires the interest and creative effort of scientists. It appears that the discussed questions are well grounded in both science and economy practice. The issue inspires further studies and analyses. The significance of work-life balance in contemporary world has undoubtedly become greater, as work as such does not exclusively serve the profit-making function: work and life complement each other and are composed in various proportions, depending on the worker's stage of life; and the organisations more often notice that the actions fostering WLB belong to the major factors that make the modern employers seem attractive to workers.

\section{Bibliography}

R. Ashkenas, Forget Work-Life Balance: It's Time for Work-Life Blend, 'Forbes', October 2012.

S.C. Clark, Work/family border theory: A new theory of work/family balance, 'Human Relations', 2000, Volume 53, Issue 6, pp. 747-770.

E. Chmielecka, Standardy ksztaltowania postaw, 'Forum Akademickie', 2002, nr 3.

D. Clutterbuck, Równowaga między życiem zawodowym a osobistym, Oficyna Ekonomiczna, Kraków 2005, pp. 26. 2627.

Eurofound, European Quality of Life Survey 2016,https://www.eurofound.europa.eu/pl/data/european-quality-of-lifesurvey [13.01.2018].

European Agency for Safety and HealthatWork, Expertforecast on emergingpsychosocial risksrelated to occupationalsafety and health, Luxemburg 2007.

S. Friedman, What Successful Work and Life Integration Looks Like, „Harvard Business Review”, October 2014.

R. Gerlach, Pozaszkolna edukacja zawodowa wobec zmian cywilizacyjnych. Nowe trendy i wyzwania, Wyd. UKW, Bydgoszcz 2012, p. 9.

M. Juchnowicz (Ed)., Elastyczne zarzadzanie kapitałem ludzkim w organizacji wiedzy, Difin, Warszawa 2007, pp. 271273.

F. Laloux, Pracować inaczej, Studio Emka, Warszawa 2016

\footnotetext{
${ }^{16}$ M. Juchnowicz (Ed).,Elastycznezarzadzaniekapitałemludzkim w organizacjiwiedzy, Difin, Warszawa 2007, pp. 271-273.

${ }^{17}$ E. Chmielecka, Standardyksztaltowaniapostaw, „Forum Akademickie”, 2002, no 3. 
N. Spinks, Work-life balance: Achievable Goal or. Pipe Dream?, 'The Journal for Quality \& Participation', 2004,Volume 27, Number 3, pp. 4-11.

R. Tomaszewska-Lipiec, Work transformations and their consequences for the personal life of workers, 'Chinese Business Review', Vol. 15, Number 5, 2016, pp. 239-248;

R. Tomaszewska-Lipiec, Praca zawodowa-życie osobiste. Dysonans czy harmonia?, UKW, Bydgoszcz 2018, p 384.

M. Westman, P. Brough, T. Kalliath, Expert commentary on work-life balance and crossover of emotions and experiences: Theoretical and practice advancements, 'Journal of Organizational Behavior', 2009, Volume 30, Issue 5, pp. 587-595. 